\title{
Cerebral venous sinus thrombosis (CVST) secondary to varicella induced hypercoagulable state in a adult
}

\author{
Barla Sudhaker ${ }^{1}$, Mutkule P. Dnyaneshwar ${ }^{2}$, Chaudhuri R. Jaidip ${ }^{2}$ and S. Manimala Rao ${ }^{3 *}$ \\ *Correspondence: manimalarao@hotmail.com

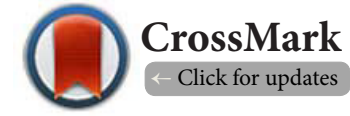

'Department of Medicine, Yashoda Hospital, Hyderabad, India.

${ }^{2}$ Department of Critical care Medicine, Yashoda Hospital, Hyderabad, India.

${ }^{3}$ Department of Neurology, Yashoda Hospital, Hyderabad, India.

\begin{abstract}
Chicken pox (Varicella) infection is generally present in children and caused by Varicella Zoster Virus (VZV). There are quite a number of case reports of hypercoagulable state leading to deep venous thrombosis (DVT) and other thromboembolic sequelae following varicella induced auto antibodies to natural anticoagulants in children. But such a clinical entity is rarely seen in adults. Here we report a rare case of CVST in an adult due to low protein $\mathrm{S}$ levels following varicella zoster infection.
\end{abstract}

Keywords: Adults, auto antibodies, thrombosis, varicella zoster, hypercoagulable

\section{Introduction}

Thrombosis of the cerebral veins and sinuses is a distinct cerebrovascular disorder. Unlike arterial stroke it most often affects young adults and children. The symptoms and clinical course is highly variable. The annual incidence is 3 to 4 cases per 1 million populations and 7 cases per 1 million among children. Around 75 percent of the adult patients are women. The neurological outcome on the whole is favorable in $80 \%$ of them. A prothrombotic risk factor or a direct cause is identified in about 85 percent of patients with venous sinus thrombosis. CVST occurrence secondary to varicella infection in an adult male is very very rare [1].

Varicella (chickenpox) is an acute exanthematous viral illness which is very common in childhood. Several case reports have been published where varicella infection is associated with acute cerebellitis, neuropathy, myelitis, encephalitis, stroke and rarely Cerebral Venous Sinus Thrombosis (CVST). We report a case report of chickenpox leading to cerebral venous thrombosis in an adult male patient with good outcome.

\section{Case presentation}

A 26 years old male, averagely built and nourished school teacher by profession presents with headache followed by generalized tonic-clonic seizures in clusters twice on the day of admission. He was apparently alright till 2 days before admission when he started having intermittent mild headache. He denied such similar episodes earlier, and had no significant medical or surgical illness in the past. He is non smoker and non alcoholic. He had chickenpox two weeks before this episode which was diagnosed by history and clinical examination and was confirmed with positive varicella lgM antibodies. He had annular scattered lesions all over the body mainly on trunk and face. He received oral acyclovir for the same. On examination he was drowsy but arousable with no focal neurological deficit. Fundus examination revealed papilloedema (Grade II) in both the eyes. His CT venogram brain showed thrombosis of Superior Sagittal Sinus as seen in Figure 1 and thrombosis of Left Transverse Sinus, Left Sigmoid Sinus and Left Internal Jugular Vein as seen in Figure 2. Patient was treated with Heparin infusion initially, and supportive care. Subsequently Vitamin $\mathrm{K}$ antagonist was started and the dose was adjusted till the INR (International Normalized Ratio) reached the therapeutic range of 2.5-3.0. His lower limb venous Doppler did not reveal any deep venous thrombosis. On further investigations he was found to have significantly low protein S levels i.e., 31\% (normal range $77-143 \%$ ) and positive antiphospholipid antibodies. His Antithrombin III, protein C levels, Hemoglobin, platelet counts and homocysteine levels were normal. He did not get any more convulsions after the hospital admission and his headache subsided gradually over a period of 4-5 days. He was discharged from the hospital on day 6.

\section{Discussion}

Varicella (chickenpox) is a common disease of childhood, 


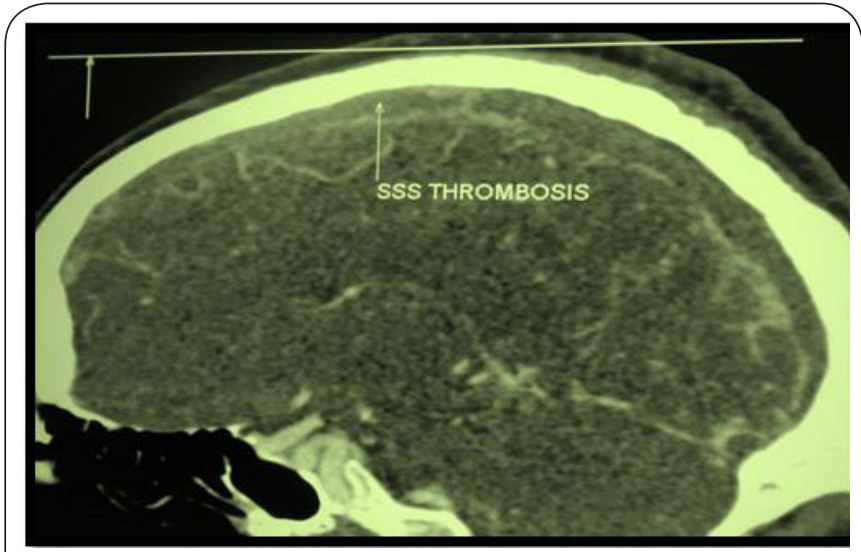

Figure 1. CT venogram showing superior sagittal sinus (sss) thrombosis.

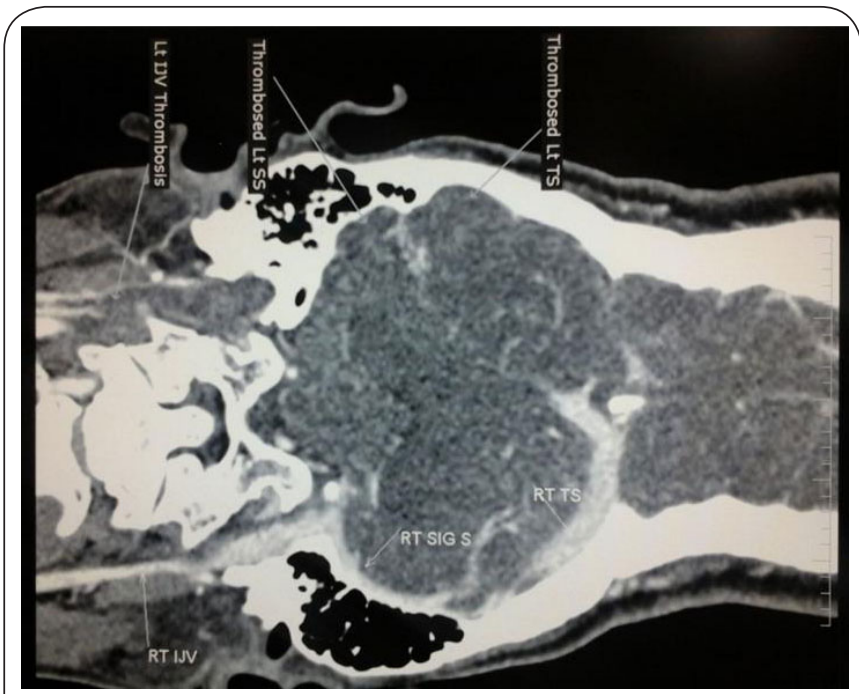

Figure 2. MPR CT venogram image showing thrombosis of transverse sinus, sigmoid sinus and internal jugular vein on the left side.

caused by varicella-zoster virus (VZV). Varicella infection commonly presents as skin manifestations like papule, vesicle and scab. Post viral thromboembolism is a rare complication of VZV in childhood. Deep venous thrombosis, pulmonary thromboembolism and cerebral venous thrombosis are rarely seen even in children. Our patient was diagnosed as cerebral venous sinus thrombosis who recovered from recent varicella infection. Antibodies developed against protein $S$ leading to hypercoagulable state. In our patient protein $S$ levels were low and anti phospholipids antibodies were positive. Ferrara M et al., (2013) reported five VZV cases with deep venous thrombosis (DVT) and concluded that acute VZV infection could be associated with coagulation disorders and production of inhibitory protein $\mathrm{S}$ antibodies [2]. Recently Januario $G$ et al., reported a case of post varicella purpura fulminans with low protein $S$ levels in a child [3]. Similar cases were reported by Van Ommen et al., describing the epitopes of these antiprotein $\mathrm{S}$ antibodies are situated on both the first 242 amino acids of protein $S$ and the sex hormone binding globulin-like domain [4]. Siddiqi et al., reported two cases of cerebral venous sinus thrombosis due to low protein $\mathrm{S}$ and C levels associated with primary Varicella Zoster infection [5]. Varicella autoantibody syndrome was described by Josephson et al., in a cross sectional study done on 95 children showing 43 of 95 children having anti phospholipids antibodies and some had significant reduction in protein S levels [6]. Most of these case reports are in children but our patient is an adult making it a rare case.

In our patient CVST was most probably as result of Hypercoagulable state due to low protein $S$ levels following development of varicella induced auto antibodies to protein S. After six months oral anticoagulants were stopped and a repeat protein C, S and anti thrombin III levels in him were found to be normal. He was found to be negative for antiphospholipids antibody this time.

\section{Conclusion}

Varicella zoster infection in an adult can rarely lead to transient reduction in the levels of natural anticoagulants there by resulting in thromboembolic phenomenon. This differential in the diagnosis can be considered when there is a recent history of chicken pox and that the other common causes of CVST have been ruled out as in our case. Early diagnosis or suspicion in these people can help prevent further damage by instituting early supportive care like adequate hydration and anticoagulant therapy as necessary for better outcome.

\section{List of abbreviations}

VZV: Varicella Zoster Virus

CVST: Cerebral venous sinus thrombosis

$\mathrm{CT}$ : Computed tomography

MPR: Multiplanar reconstruction

SSS: Superior Sagittal sinus

SS: Sigmoid sinus

TS: Transverse Sinus

IJV: Inferior Vena Cava

\section{Competing interests}

The authors declare that they have no competing interests.

\section{Authors' contributions}

\begin{tabular}{|l|c|c|c|c|}
\hline Authors' contributions & BS & MPD & CRJ & SMR \\
\hline Research concept and design & -- & -- & -- & $\checkmark$ \\
\hline Collection and/or assembly of data & $\checkmark$ & -- & -- & $\checkmark$ \\
\hline Data analysis and interpretation & $\checkmark$ & $\checkmark$ & -- & $\checkmark$ \\
\hline Writing the article & $\checkmark$ & $\checkmark$ & -- & -- \\
\hline Critical revision of the article & -- & $\checkmark$ & $\checkmark$ & -- \\
\hline Final approval of article & -- & $\checkmark$ & $\checkmark$ & $\checkmark$ \\
\hline Statistical analysis & -- & -- & -- & -- \\
\hline
\end{tabular}

\section{Acknowledgement}

We gratefully acknowledge the Neurophysicians, Radiologists, 
Sudhaker et al. Internal Medicine Inside 2014,

http://www.hoajonline.com/journals/pdf/2052-6954-2-1.pdf

nurses and management of the Yashoda Hospital for their valuable support.

\section{Publication history}

Editor: Francesca Pistoia, University of L'Aquila, Italy.

EIC: Fabio Angeli, University of Perugia, Italy.

Received: 17-May-2014 Final Revised: 26-Jun-2014

Accepted: 09-Jul-2014 Published: 31-Jul-2014

\section{References}

1. Stam J. Thrombosis of the cerebral veins and sinuses. N Engl J Med. 2005; 352:1791-8. I Article I PubMed

2. Ferrara M, Bertocco F, Ferrara D and Capozzi L. Thrombophilia and varicella zoster in children. Hematology. 2013; 18:119-22. | Article | PubMed

3. Januario G, Ramroop S, Shingadia DV and Novelli V. Postinfectious purpura fulminans secondary to varicella-induced protein $\mathrm{S}$ deficiency. Pediatr Infect Dis J. 2010; 29:981-3. I Article I PubMed

4. Van Ommen $\mathrm{CH}$, van Wijnen $\mathrm{M}$, de Groot FG, van der Horst $\mathrm{CM}$ and Peters M. Postvaricella purpura fulminans caused by acquired protein s deficiency resulting from antiprotein s antibodies: search for the epitopes. J Pediatr Hematol Oncol. 2002; 24:413-6. I Article I PubMed

5. Siddiqi SA, Nishat S, Kanwar D, Ali F, Azeemuddin M and Wasay M. Cerebral venous sinus thrombosis: association with primary varicella zoster virus infection. J Stroke Cerebrovasc Dis. 2012; 21:917 e1-4. | Article I PubMed

6. Josephson C, Nuss R, Jacobson L, Hacker MR, Murphy J, Weinberg A and Manco-Johnson MJ. The varicella-autoantibody syndrome. Pediatr Res. 2001; 50:345-52. I Article I PubMed

\section{Citation:}

Sudhaker B, Dnyaneshwar MP, Jaidip CR and Rao SM. Cerebral venous sinus thrombosis (CVST) secondary to varicella induced hypercoagulable state in a adult. Intern Med Inside. 2014; 2:1.

http://dx.doi.org/10.7243/2052-6954-2-1 